\title{
SZIMBOLIKUS TEMETKEZÉSEK ÉS GYÁSZ \\ Traumakezelési stratégiák a Kárpát-medence újkőkorában és rézkorában
}

\section{Hegedús ZsuZsA ${ }^{1}$}

Magyar Régészet 10. évf. (2021), 3. szám, pp. 13-22. https://doi.org/10.36245/mr.2021.3.2

A Kárpát-medence késö újkökorában és rézkorában több példáját is megtaláljuk a szimbolikus, azaz holttestet nem tartalmazó temetkezéseknek. Kialakitásuk egyik célja az lehetett, hogy a temetkezési ritusok során fókuszpontként szolgáljanak azokban az esetekben, mikor a közösség egy tagját nem lehetett megfelelö módon elbúcsúztatni. Ezáltal feltételezhetjük, hogy szerves részét alkották a gyász- és traumakezelési szokásoknak. Leletanyaguk elemzése egyes esetekben arra is lehetöséget ad, hogy bizonyos szintig rekonstruáljuk a hozzájuk köthetö identitásokat.

Kulcsszavak: gyász, neolitikum, rézkor, szimbolikus temetkezés

A szimbolikus, holttestet nem tartalmazó temetkezések évezredek óta jelen vannak a különböző kultúrákban, ma is gyakran találkozunk velük, például háborús emlékmüvek formájában. A Kárpát-medencében legkorábbi megjelenéseik az újkőkorhoz és az ezt követő rézkorhoz kapcsolódnak. Az időszakra jellemző nagy változatosságuk indokolttá teszi összefoglalásukat, a mögöttes jelentéseik feltárását (HeGEDưs in press). Jelen cikkben a gyász feldolgozásában és a traumakezelésben játszott szerepükre fókuszálva mutatom be a jelképes temetkezéseket.

\section{A GYÁSZ MINT TRAUMA}

Európában a Neandervölgyi emberek közösségei voltak azok, akik a középső paleolitikum időszakában (mintegy 250-50 ezer évvel ezelött) elöször temették el halottaikat (Hovers \& BELFER-COHEN 2013, 633). Az idők során sokszor és sokat változtak a szokások, így nem is feltétlenül tudjuk megfejteni, milyen mozzanatok mögött milyen gondolatiság és érzelmek álltak. Mégis, a közösség egy tagjának halálához köthető gyász, mint a veszteségre adott természetes reakció, általános emberi jelenség. Egy személy halála lyukat üt a stabilnak hitt társadalmi szövetben, sokkos állapotot idéz elő a saját haladóságukkal is szembesülö, az elhunythoz érzelmileg kötődő túlélőkben (NiLsSEN Stutz \& TARLow 2013, 7). A gyász megjelenése, intenzitása azonban erősen változékony lehet (ARCHER 1999, 1-8), ahogy az is, hogy milyen folyamatokon keresztül oldódik fel. Egyes, a pszichológiában alkalmazott modellek lépésekre bontják a gyógyulást (pl. RANDO 1984; KÜBLER-Ross \& KESSLER 2005; WoRDEN 2009), míg mások egy dinamikus, állandóan változó folyamatként írják le azt (StroEBE \& Schut 1999). A gyász lefolyásához hasonlóan rendkívül változatosak lehetnek azok a halottkezelési technikák, melyek a halál miatt kialakult krízishelyzet feloldására jöttek létre (Reimers 1999, 148; Fahlander \& Oestigaard 2008, 1; Nilssen Stutz \& Tarlow 2013, 6). A „praktikus”, azaz a holttest elhelyezésével kapcsolatos mozzanatokon túl a rítusoknak kiemelkedő szerepe van abban, hogy a mindennapok rendjét visszaállítsák, összekössék a közösség tagjait térben és időben, így csökkentve a halál által jelentett fenyegetést (Assmann 2005, 28; Pérez \& Weiss-Krejci 2011, 108; Bailey \& Walter 2016, 151). Ezeken a rítusokon, és a holttest manipulációján keresztül a halált is értelmezhető, saját kulturális eszközeikkel feldolgozható formába öntik a gyászolók (NILSSEN STUTZ \& TARLOw 2013, 6).

Mind a gyász feldolgozása, mind a rítusok során fontos mozzanat az, hogy a közösség interakcióba lépjen a temetkezési rítusok és az érzelmek fókuszában elhelyezkedő holttesttel. Erre nem mint biológiai

Eötvös Loránd Tudományegyetem, Bölcsészettudományi Kar, Történelemtudományi Doktori Iskola, Régészet Doktori Program, PhD hallgató. E-mail: zshegedus@student.elte.hu 
Hegedüs Zsuzsa $\bullet$ Szimbolikus temetkezések és gyász

entitásra, hanem mint egyénre tekintenek (NiLssen Stutz \& Tarlow 2013, 7; Kus 2013, 60). A test és az ezzel létrehozott kapcsolat hiányában a halál élményének befogadása sokkal nehezebb (FARO 2014, 17). Az elhunyt hiánya a temetkezés lefolyását és a gyász feldolgozását is megakaszthatja (WeISS-KREJCI 2011, 76). Ha nem mennek végbe a szükséges folyamatok - mind fizikális, mind pszichológiai értelemben akkor a közösség tagjai a lezáratlan gyász traumatikus, szinte bénító helyzetében találhatják magukat (Boss 1999, 2-6). Ha valaki például eltünik és nincs meg a bizonyosság arról, hogy mi történt vele, még hosszú idő múltán is élhet a sokszor irracionális remény, hogy visszatérhet a közösségbe (ZUR 1998, 206). Ez a bizonytalanság ellehetetleníti azt, hogy a halál beálltát követő jól begyakorolt, és a gyász feloldásában kifutó eseménysor meginduljon. Az érintettek a traumatikus élményben ragadnak, folyamatosan negatív érzelmeknek vannak kitéve, és ha a megrázkódtatást egyáltalán nem lehet feldolgozni, ez az állapot állandósul. Ilyenkor a csoporton belül is növekedhet a feszültség, mivel felborul a közösség megszokott élete, és a halott elbúcsúztatásának szükséges rítusai nélkül nem jelennek meg a csoporton belüli kölcsönös támogatórendszerek sem (Boss 1999, 8-24).

Mindezek miatt tehát szükséges lehetett, hogy a közösségek különböző ,alternatív” megoldásokat alakítsanak ki. Ezekkel lehetőség nyílt arra, hogy megemlékezzenek az elhunytakról, felszínre hozva a megfelelő érzelmeket (WeIss-KREJCI 2013, 283-289) és a rítusok elvégzésével közelebb hozva a közösség tagjai számára a gyógyulást (ZuR 1998, 209). A szimbolikus temetkezések létrehozása egy ilyen megoldás lehetett. A régészeti adatokra támaszkodva bizonyos fokig rekonstruálni lehet a szokások mögötti gondolatokat, célokat (COOLIDGE \& WyNN 2016, 386), így mélyebb és árnyaltabb képet kaphatunk a jelképes temetkezésekről.

\section{A SZIMBOLIKUS TEMETKEZÉSEK SZEREPE}

A jelképes temetkezések úgy definiálhatók, mint egy közösség temetkezési szokásaiba jól beillő, annak eszközeit felhasználó, azonban a temetkezéseknél nagyobb információhordozó képességgel rendelkező objektumok. Bár megjelenésük, kialakításuk sokszor megegyezik az „átlagos” sírokéval, szélesebb körü funkciókat láttak el (HEGEDŰs in press). A kenotáfium kifejezés is használatos a jelenségre, azonban ez inkább az ókorban megjelenő szimbolikus temetkezésekre vonatkoztatható, ami miatt nem tartom célszerünek az őskori objektumokkal kapcsolatos alkalmazását. A római császárkor jelképes temetkezéseiről Novotnik Ádám írt bővebben (Novotnik 2019).

A szimbolikus temetkezések egy funkciója a közösségi gyászhoz és traumakezeléshez kapcsolódóan az lehetett, hogy olyan embereknek állítottak emléket, akik földi maradványait nem tudták eltemetni (1. kép). Több oka lehetett annak, hogy valakinek a teste miért nem volt jelen a temetéskor - például eltünhetett, balesetben, erőszakos konfliktusban, vagy egyéb tragikus módon lelhette halálát a közöségtől távol (BoGNÁRKuTZIÁN 1963, 368-369). Ennek ellenére nem feltételezhetjük, hogy minden eltünt, távolban elhunyt személy jelképes temetkezést kapott, hiszen nem mindenkit kezeltek ugyanúgy. Különböző szempontok érvényesülhettek abban, milyen rítussal temették el a közösség bizonyos tagjait. Sok olyan halottkezelési módszerrel is számolhatunk, melynek nem maradtak régészetileg megfogható nyomai (PRICE 1997, 114; WeISS-KREJCI 2013, 285; KirÁly 2016, 279-299).

A traumakezelésen túl két másik funkció betöltésére is létrehozhattak jelképes temetkezéseket (HEGEDüs in press). A kiemelkedően gazdag, szinte kincsleletszerü együttesek jellemezte egyik típus (CHAPMAN 2000, 127; RACHEV 2018, 51) fö célja nem az lehetett, hogy egy konkrét személyhez kötődjön. Helyette inkább egy absztrakt, elvont identitás vagy fogalom tiszteletét volt hivatott kifejezni (STRATTON 2016, 201), feltehetőleg közösségi rítusokhoz erősen kapcsolódva. Ebben az esetben az értékes, nagy mennyiségben megjelenő tárgyak a halott testétől függetlenül voltak képesek kiemelkedő társadalmi helyzetet vagy gazdagságot kommunikálni (CHAPMAN 2000, 182; JoNEs 2007, 43). A jelképes temetkezések harmadik típusának az emlékhelyként funkcionáló, térben erösen összetett objektumokat tarthatjuk. Ezek feladata az volt, hogy több elhunytat egyszerre szimbolizáljanak, ezen keresztül pedig alakítsák a közösségi emlékezetet (JONES 2007, 41; DANILOVA 2015, 11-14). Segítségükkel az elhunytak maguk is szimbólummá válnak, hiszen összekapcsolódnak egy olyan kifejezni kívánt üzenettel, mely akár a hatalom manipulálására is alkalmas volt (DANILOVA 2015, 1-6). 


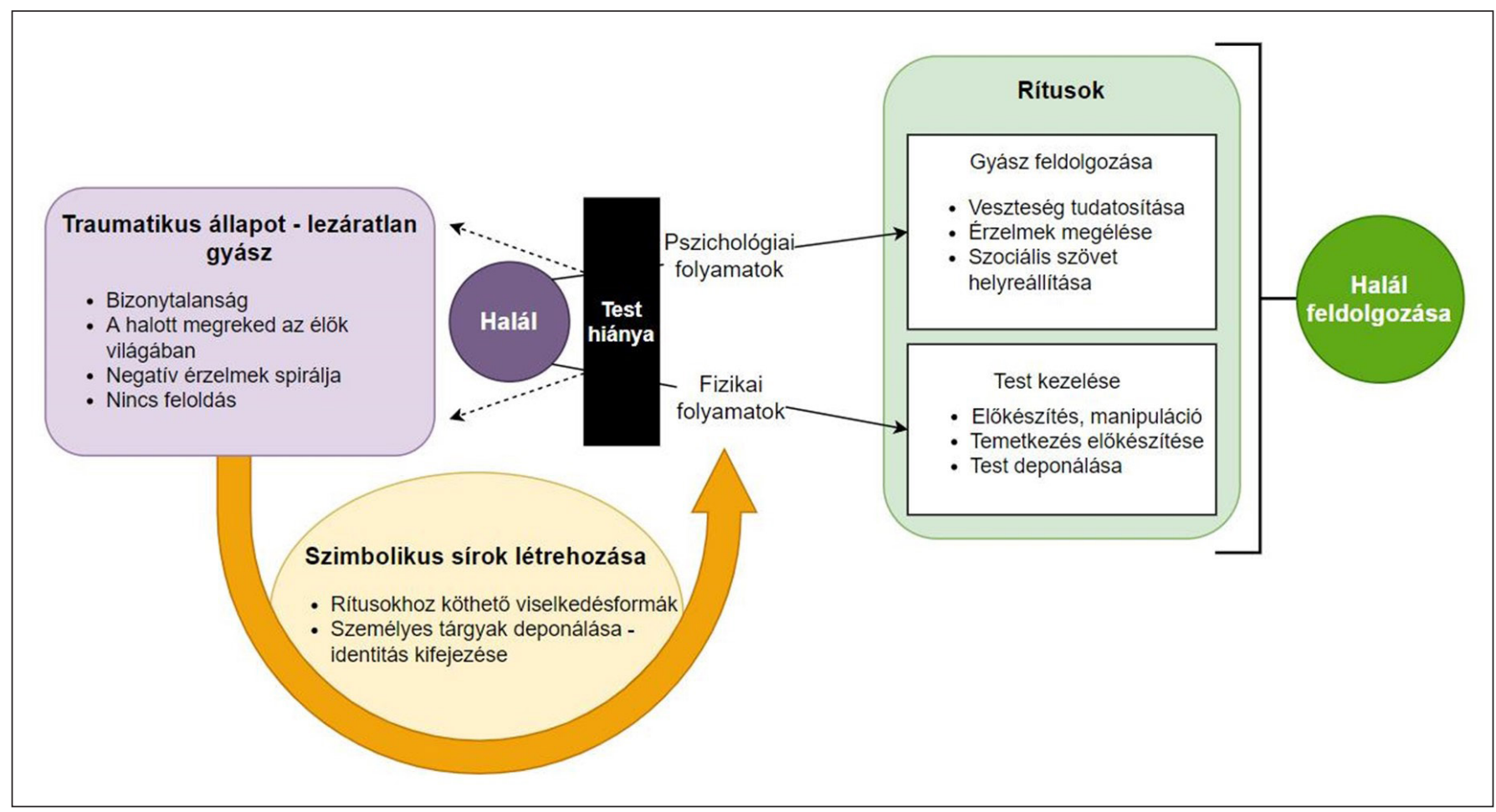

1. kép. A holttest hiányában a halálhoz köthetö viselkedésformák, rítusok nem tudnak megfelelöen végbemenni, így ellehetetlenül a veszteség feldolgozása. Ilyenkor komoly segitséget jelenthet a szimbolikus temetkezések létrehozása, mely lehetövé teszi a gyász megélését

A szimbolikus temetkezések több formában és funkcióval jelentek meg, tehát nemcsak a gyászkezelésben játszottak szerepet. Mégis, éppen ez a traumakezeléshez kapcsolódó színezetük volt az, ami feltehetöleg a temetkezési szokások szabadabb átalakításának kezdetét jelenthette (HEGEDüs in press), és melynek vizsgálata közelebb vihet minket az egykor élt emberek halálhoz való viszonyának megértéséhez.

\section{A VIZSGÁLT TÉR ÉS IDŐ}

A Kárpát-medencében a jelképes temetkezések létrehozásának szokása a késő újkőkorban (5000-4500/4400 BC) gyökerezik (BognÁr-Kutzián 1963, 369). Ez az Alföldön a nagy tellek és a Dunántúlon a szintén hatalmas körárokrendszerek létrehozásának, tehát a komoly és szoros közösségi együttmüködéseknek a kora volt. A kor emberei halottaikat a telepek erre kijelölt részein temették el, nagy gondossággal, egyes esetekben gazdag mellékletekkel (RACZKY 2016; RACZKY 2019, 272-279). A tellek megszűnésével az erős társadalmi kapcsolatok a rézkorban (4500/4000-2800 BC) sem tüntek el, ekkor számolhatunk az első, nagy sírszámú, nem telepekhez kapcsolódó temetők megjelenésével. A rézkor kezdetén a késő újkőkori temetkezési szokások továbbélesét látjuk összefonódni a réz és az arany - a korszakban kiemelkedő társadalmi helyzetet és presztízst kifejező anyagok - használatával (PARKINSON et al. 2010; RACZKY et al. 2014). A késő rézkorra az életmód változása, a közösségek mobilabbá válása a rítusokban is leképeződött, például a szarvasmarha szimbolika megerősödésében (RACZKY 2009; BonDÁR 2015, 281-290).

A változások ellenére a szimbolikus temetkezések létrehozásának szokása megmaradt, folyamatosan átalakulva és alkalmazkodva az adott korszak, közösség temetkezési szokásaihoz. Itt megjegyzendö, hogy nem minden kultúrában találkozunk velük, inkább csak ott, ahol egyébként is erős hangsúlyt kaptak azok a temetkezési formák, melyeket aztán régészeti eszközökkel megfoghatunk. Így például a középső rézkorban a Dunántúlon megjelenő Balaton-Lasinja kultúra köréből - melynek egyébként is csak viszonylag kevés sírját ismerjük (REGENYE 2006, 15; KöHLER 2006, 41) - nem ismerünk szimbolikus temetkezéseket. Az ilyen közösségek feltehetöleg más temetkezési rítusokat és traumakezelési eszközöket részesítettek előnyben. 
Hegedüs Zsuzsa $•$ Szimbolikus temetkezések és gyász

\section{EGYÉNEKNEK EMLÉKET ÁLLÍTÓ SZIMBOLIKUS TEMETKEZÉSEK A KÁRPÁT-MEDENCÉBEN}

Az egykori közösségek feltehetőleg konkrét személyeket láttak a sírba került tárgyak mögött az egyéneknek emléket állító szimbolikus temetkezések esetében (CHAPMAN 2000, 122). Így ezek elkészítésében, felszerelésében ugyanazok az elvek érvényesülhettek, mint amik a test jelenlétében érvényesültek volna. A temetkezési rítusok során nagy hangsúly van azokon az elemeken, melyek az adott egyén identitását, azaz különbözö, a közösségben fontosnak tartott tulajdonságai, kapcsolatai alapján kialakított hovatartozását voltak hivatottak kifejezni (DíAZ-ANDREu \& LuCY 2005, 1-2). Bár az identitás kifejezése annak teljes komplexitásában történhetett, figyelembe kell vennünk, hogy az identitások teljességét nem tudjuk régészeti eszközökkel megfogni (Stratton \& Boric 2012, 77-78; Stratton 2016, 211; Koncz \& Szilágyi 2017). Továbbá azt is szem előtt kell tartanunk, hogy a temetkezések vizsgálatakor nyert adatok rendkívül komplexek (HÄrKE 1997). Emiatt az egyes jelenségek, együttesek értelmezése még akkor is nehéz, amikor „teljesnek és átlagosnak” tekinthető sírokkal állunk szemben. A szimbolikus temetkezéseknél tovább nehezíti az elemzést a holttest teljes hiánya, hiszen a halott földi maradványaiból leolvasható adatok (például a kor és a biológiai nem) az elhunyt identitásának kialakításában, és ezen keresztül annak sírban történő megjelenítésében is komoly szerepet játszottak.

A Kárpát-medencében nyolc olyan lelöhelyet ismerünk, ahonnan bizonyítottan szimbolikus temetkezés került elő (2. kép). Innen 1180 sír közül vizsgáltam 32 olyan bolygatatlan jelképes temetkezést, mely egyéneknek állíthatott emléket (HEGEDÜs in press). ${ }^{2}$ Ezen objektumok esetében felmerül annak a lehetősége, hogy adott szinten beazonosítsuk, kihez lehetett őket kötni.

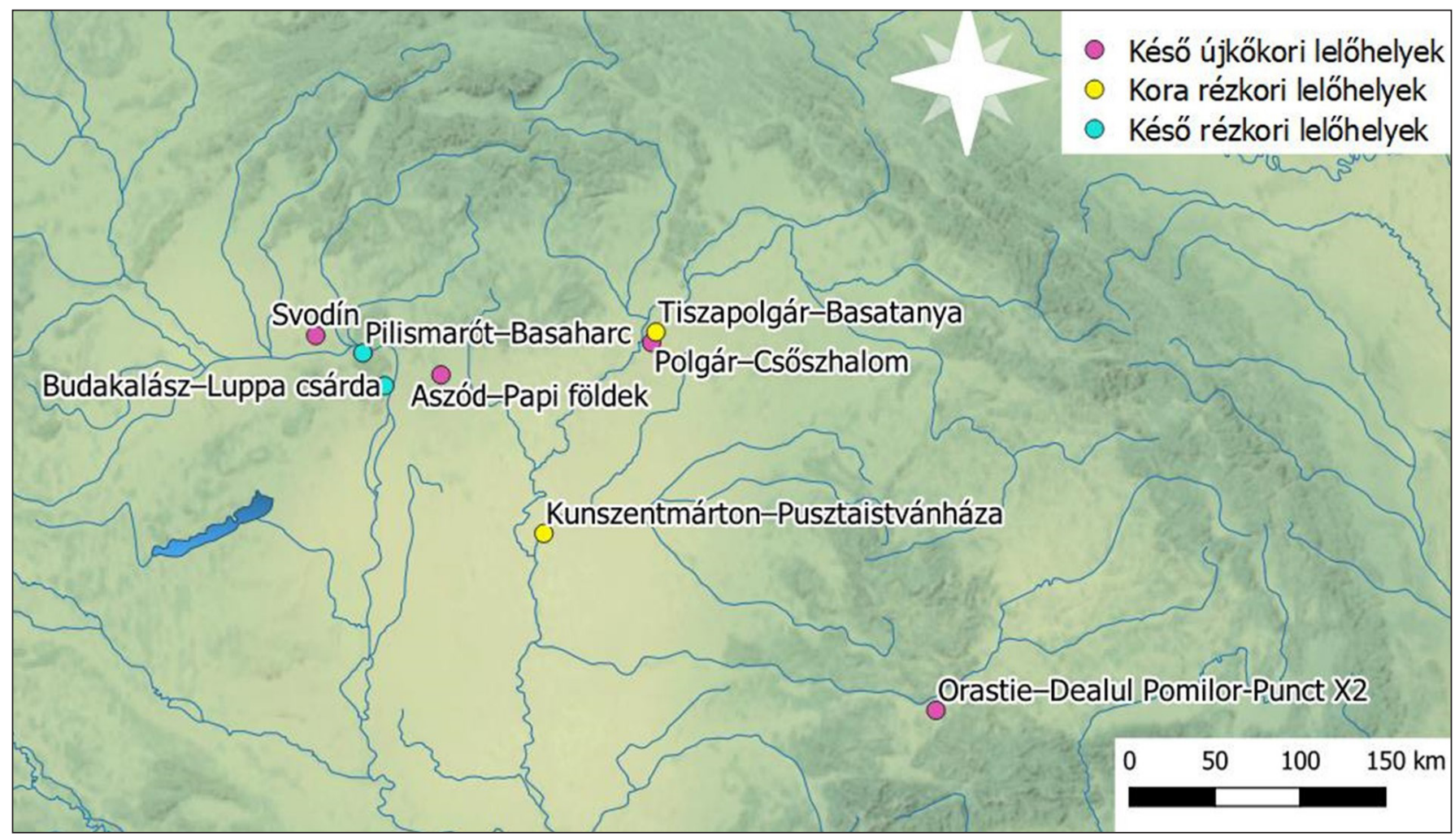

2. kép. A Kárpát-medence késö újkőkorának, kora és késő rézkorának lelöhelyei, ahonnan egyénekhez köthető szimbolikus temetkezések kerültek elö

Aszód-Papi földekről egy (SiKLósi 2013, 113-122), Budakalász-Luppa csárdáról három (BondÁR 2009, 92-159), Kunszentmárton-Pusztaistván házáról egy (Hillebrand 1927, 24-28), Orastie-Dealul Pomilor-Punct X2/Platoul Romposról kettő (LuCA 2006, 17-19), Pilismarót-Basaharcról 21 (Bondér 2015, 32-98), Polgár-Csőszhalom horizontális telepéről egy (Raczky \& Anders 2009, 84), Svodínról kettő (NemejcovÁ-Pavuková 1986, 148; Zalai-GaÁl 1988, 68), TiszapolgárBasatanyáról egy (BoGNÁR-KuTZiÁn 1963, 77-79) egyénhez köthető szimbolikus temetkezés ismert. 
Hegedüs Zsuzsa $\bullet$ Szimbolikus temetkezések és gyász

Az adott temetkezési helyek sírjaiból és a jelképes temetkezésekből ismert leletegyüttesek összehasonlító vizsgálatára alapozva történt meg az identitások rekonstrukciójához szükséges tendenciák meghatározása. Mivel egy adott tárgy számos különböző jelentést képes hordozni, fontos a leletek egymáshoz és teljes környezetükhöz füződő viszonyát felderíteni. Ezt több tényezőt egyszerre vizsgáló, a sokszor rejtett összefüggések felderítésére is alkalmas statisztikai elemzésekkel lehet megtenni (például főkomponens- és korrespondencia-analízissel). Az elhunyt biológiai neme és a vele eltemetett tárgyak összefüggései azok az információk, melyekből kiindulhatunk amikor a temetőkből ismert bolygatatlan sírokat vizsgáljuk. Ebből felvázolhatóak nemekhez kapcsolódó identitásokat (GoLSE 2016) mutató csoportok, mely csoportok összehasonlítási alapot adnak a jelképes temetkezések leletanyagának vizsgálatakor. ${ }^{3}$ Így például ha a közösség bizonyos társadalmi szerepeket betöltő férfijainak sírjába vaddisznóállkapcsot és rézbaltát helyeztek, az ilyen leleteket tartalmazó szimbolikus temetkezések is feltehetőleg hasonló szerepkörü férfiaknak készülhettek (3. kép). A Tiszapolgár-Basatanya lelőhely (BognÁR-KuTZián 1963) Tiszapolgár stílusú edényekkel eltemetett, bolygatatlan sírú egyéneinek sírmellékleteit a halottak biológiai nemei alapján összevető vizsgálat a leletek összefüggései alapján feltárja, milyen csoportokat különíthetünk el. Az egyes csoportok közti nagyobb átfedés arra utal, hogy bár lehettek az egyes egységeknek jellemző mellékletei, nem beszélhetünk kizárólagosságról. A lelőhely 29. számú szimbolikus temetkezése (melyből edények, réz ékszertöredékek, állatcsontok - köztük egy vaddisznó állkapcsa - és mészkőgyöngyök kerültek elö) legjobban a gyermektemetkezések együtteseihez hasonlítható. Ezt alátámasztja, hogy leginkább a 4. és 18. gyermeksírok leletegyüttesének összetétele hasonlít a szimbolikus temetkezésére, továbbá a sírgödör kisebb mérete is erre utalhat (3. kép).

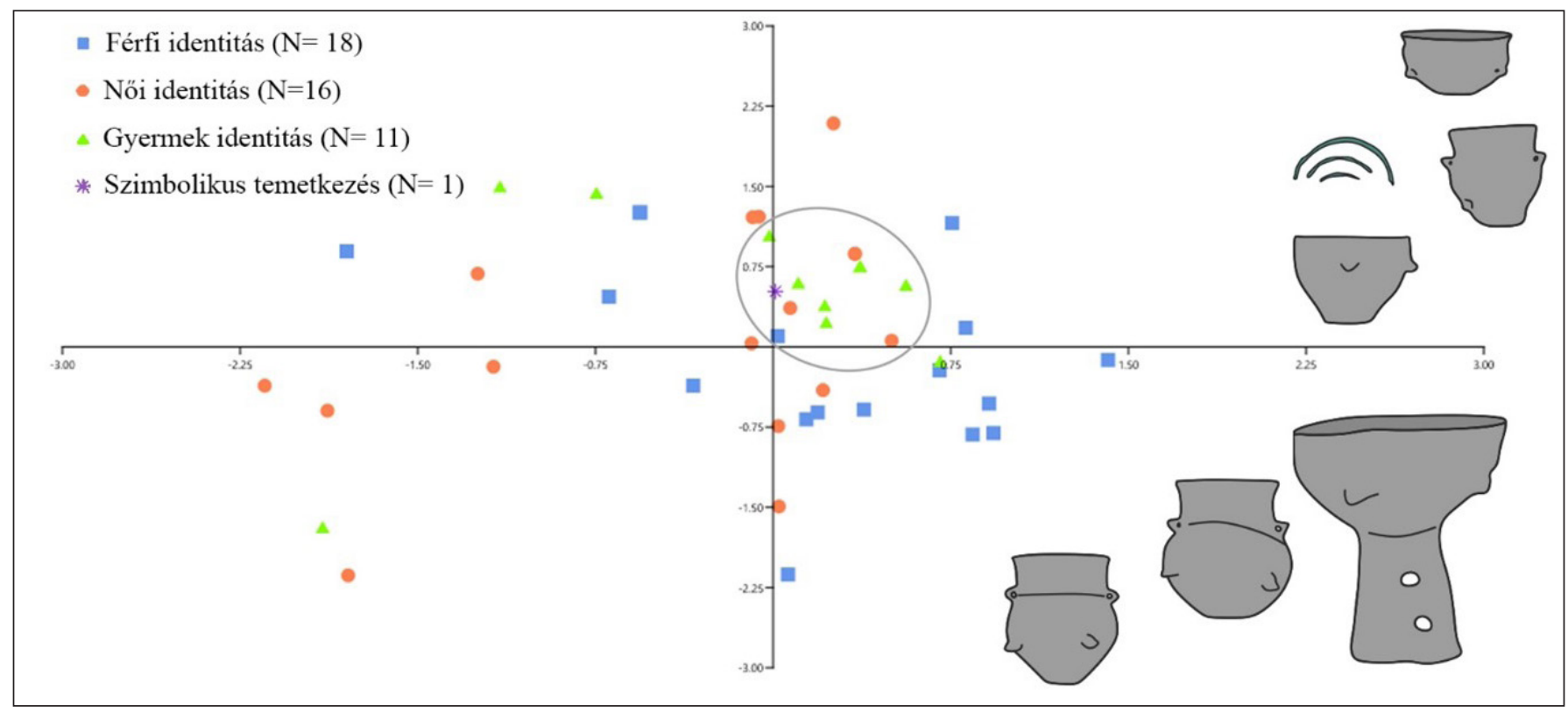

3. kép. Tiszapolgár-Basatanya lelöhely (BOGNÁR-KUTZIÁN 1963) Tiszapolgár stílusú kerámiával felszerelt sírjainak korrespondencia-analizise, a halottak biológiai nemei alapján színezve. A 29. számú sír, melynek mellékletei az ábrán láthatóak, legjobban a gyermektemetkezésekkel mutat hasonlóságot

A fentebb bemutatott módszerrel 32 szimbolikus temetkezés közül hét esetben férfi, egyben nö és két alkalommal gyermek identitást lehetett rekonstruálni. A gyermekeknek szánt szimbolikus temetkezések megjelenése érdekes kérdéskört feszeget: hogyan viszonyultak a szimbolikus temetkezéseket létrehozó közösségek (és úgy általában az őskori emberek) a gyermekek halálához? A magas gyermekhalandóság (GoodMAN \& Armelagos 1989, 255) jelentette folyamatos fenyegetettség ellenére is feltételezhetö, hogy a közösségeket megrázta a legkisebbek halála, nem csak érzelmi, szociális, hanem gazdasági tekintetben is (THOMAs 2020,

3 Itt a férfi és nő kategóriák mellett harmadikként megjelenik a gyermekek csoportja is, azokban az esetekben, mikor túl fiatal volt az eltemetett egyén a nem antropológiai meghatározásához (SoFAER-DEREVENSKI 1997). 
Hegedüs Zsuzsa • Szimbolikus temetkezések és gyász

4454). Egyfajta védekezési mechanizmus lehetett az, hogy csak bizonyos életszakaszok után kezdték a gyermekeket a közösség teljes jogú tagjainak tekinteni, és az ehhez illeszkedő rítusok szerint temetni (McHugh 1999, 19-20). Ennek értelmében pedig az, hogy a gyerekek is kaptak szimbolikus temetkezéseket, egyértelmüen a felnőttek szintjére, vagy annak közelébe emelte öket. Összesen 22 esetben nem lehet következtetni a jelképes temetkezésekhez köthető identitásra, illetve a biológiai nemre. Ez nagyrészt annak köszönhetö, hogy Pilismarót-Basaharc lelöhelyen (BONDÁR 2015) hamvasztásos rítussal számolhatunk, ami az esetek többségében ellehetetlenítette az elhunytak biológiai nemének megállapítását (KÖHLER 2015, 322). Így itt 21 esetben sajnos nem lehetett rekonstruálni a jelképes temetkezésekhez köthető identitást (4. kép).

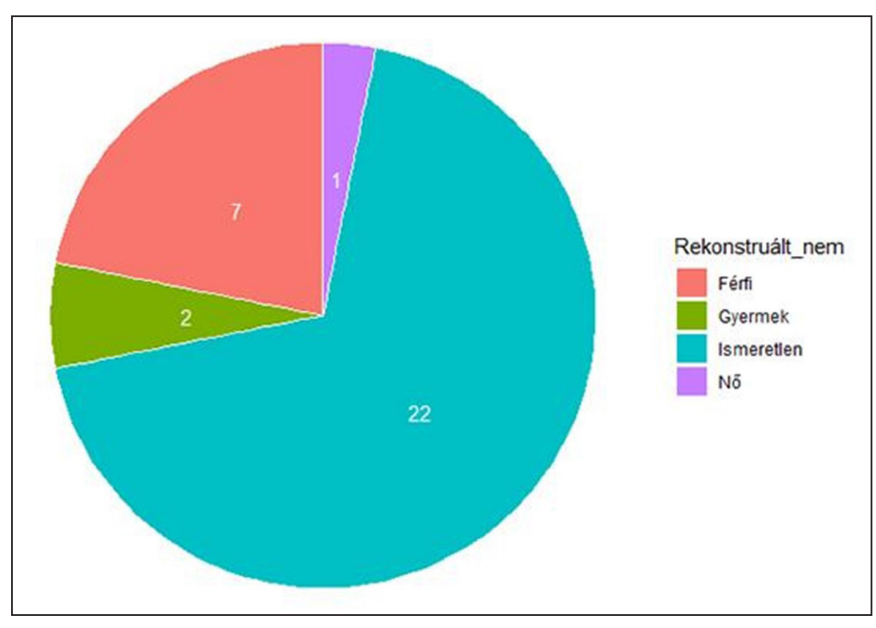

4. kép. A Kárpát-medence késő újkőkorának és rézkorának szimbolikus temetkezései közül összesen 32 kötödhetett tényleges egyénekhez. Ezen személyek feltételezett nemhez köthetö identitását bizonyos esetekben rekonstruálni is lehetett

\section{ÖSSZEGZÉS}

A szimbolikus temetkezések változatos, számos szerepet betölteni képes objektumként jelentek meg a Kárpát-medence késő újkőkorában és rézkorában. Elsősorban azon közösségek rítuskészletében találunk jelképes temetkezéseket, melyeknél egyébként is hangsúlyosabbak a régészeti nyomokat is hagyó szokások. A szimbolikus temetkezések konkrét személyeknek emléket állító formája komoly szerepet játszhatott az egyének és a közösség gyászfeldolgozásában, traumakezelésében. Létrehozásuk olyan stratégiának tekinthető, mely - igazodva az egyes csoportok temetkezési szokásaihoz - alkalmas volt a komoly érzelmi megrázkódtatás, és akár a szociális feszültségek feloldására is. Bizonyos fokig lehetőségünk van rá, hogy megvizsgáljuk, milyen identitások köthetőek a jelképes temetkezésekhez, a kontextusukat jelentő sírok, az elhunyt személyek biológiai neme és a tárgyak összefüggése alapján. Ebből kitünik, hogy nagy részük férfi identitású egyénekhez köthető, de a női és gyermek jellegek is megjelennek, mely a szokás általános voltára enged következtetni. Összességében tehát az első látásra kevéssé információdúsnak tűnő, üres sírok vizsgálata is fontos adalékokkal szolgálhat az egykori szokások és a mögöttük álló emberi vonások értelmezésében.

\section{AJÁNLOTT IRODALOM}

Boss, P. (1999). Amiguous Loss. Learning to Live with Unresolved Grief. Cambridge, London: Harvard University Press. https://doi.org/10.2307/j.ctvjhzrh4

Fahlander, F. \& Oestigaard, T. (2008). The materiality of death: bodies, burials, beliefs. In Fahlander, F. \& T. Oestigaard (eds), The Materiality of Death: Bodies, Burials, Beliefs (pp. 1-16). Oxford: Archaeopress. https://doi.org/10.30861/9781407302577

Király, Á. (2016). A terminológia halálától a halál terminológiájáig. Megjegyzések a temetkezés fogalmához és a temetkezési ciklus állomásainak nevezéktanához. Tisicum. A Jász-Nagykun-Szolnok megyei Múzeumok Évkönyve 25, 297-302.

Rebay-Salisbury, K., Stig Sørensen, M.L. \& Hughes, J. (eds) (2010). Body Parts and Bodies Whole: Changing Relations and Meanings. Oxford, Oakville: Oxbow Books. 
Hegedüs Zsuzsa $\bullet$ Szimbolikus temetkezések és gyász

Weiss-Krejci, E. (2013). The unburied dead. In Tarlow, S. \& Nilsson Stutz, L. (eds), The Oxford Handbook of the Archaeology of Death and Burial (pp. 281-302). Oxford: Oxford University Press. https://doi. org/10.1093/oxfordhb/9780199569069.013.0016

\section{FELHASZNÁLT IRODALOM}

Archer, J. (1999). The Nature of Grief. The Evolution and Psychology of Reactions to Loss. London: Brunner-Routledge. https://doi.org/10.4324/9780203360651

Assmann, J. (2005). Die Lebenden und die Toten. In Assmann, J., Maciejewski, F. \& Michaels, A. (eds), Der Abschied von Den Toten: Trauerrituale Im Kulturvergleich (pp. 16-36) Göttingen: Wallstein Verlag. https://doi.org/10.5771/9783835320819-16

Bailey, T. \& Walter, T. (2016). Funerals against death Mortality 21 (2), 149-166. https://doi.org/10.1080/1 $\underline{3576275.2015 .1071344}$

Bognár-Kutzián, I. (1963). The Copper Age Cemetery of Tiszapolgár-Basatanya. Budapest: Akadémiai Kiadó.

Bondár, M., 2009, The cemetery. In Bondár, M. \& Raczky, P. (eds), The Copper Age Cemetery of Budakalász (pp. 11-302). Budapest: Pytheas Printing House.

Bondár, M. (2015). The archaeological assessment of the Pilismarót-Basaharc cemetery. In Bondár, M., T. Bíró, K., Gál, E., Hamilton, D., Köhler, K. \& Torma, I., The Late Copper Age Cemetery at PilismarótBasaharc. István Torma's Excavations (1967, 1969-1972) (pp. 9-318). Budapest: Institute of Archaeology, Research Centre for the Humanities, Hungarian Academy of Sciences.

Boss, P. (1999). Amiguous Loss. Learning to Live with Unresolved Grief. Cambridge, London: Harvard University Press. https://doi.org/10.2307/j.ctvjhzrh4

Chapman, J. (2000). Fragmentation in Archaeology: People, Places, and Broken Objects in the Prehistory of South-Eastern Europe. London, New York: Routledge. https://doi.org/10.4324/9780203759431

Coolidge, F. L. \& Wynn, T. (2016). An introduction to cognitive archaeology. Current Directions in Psychological Science 25 (6), 386-392. https://doi.org/10.1177/0963721416657085

Danilova, N. (2015). The Politics of War Commemoration in the UK and Russia. London: Palgrave Macmillan.

Díaz-Andreu, M. \& Lucy, S. (2005). Introduction. In Díaz-Andreu, M., Lucy, S., Babić, S. \& Edwards, D.N. (eds), Archaeology of Identity: Approaches to Gender, Age, Status, Ethnicity and Religion (pp. 1-12). London, New York: Routledge.

Fahlander, F. \& Oestigaard, T. (2008). The materiality of death: bodies, burials, beliefs. In Fahlander, F. \& T. Oestigaard (eds), The Materiality of Death: Bodies, Burials, Beliefs (pp. 1-16). Oxford: Archaeopress. https://doi.org/10.30861/9781407302577

Faro, L. M. C. (2014). Monuments for stillborn children: Coming to terms with the sorrow, regrets and anger. Thanatos 3(2), 13-30. 
Hegedüs Zsuzsa $\bullet$ Szimbolikus temetkezések és gyász

Golse, B. (2016). Identité sexuée ou identité sexuelle? D’un genre à l'autre. Le Carnet PSY 2 (196), 1. https://doi.org/10.3917/lcp.196.0001

Goodman, A. H. \& Armelagos, G. J. (1989). Infant and childhood morbidity and mortality risks in archaeological populations. World Archaeology, 21 (2), 225-243.

Härke, H. (1997). The nature of burial data. In Jensen, C.K. \& Nielsen, K.H. (eds.), Burial \& Society. The Chronological and Social Analysis of Archaeological Burial Data (pp. 19-27). Arhus: Aarhus University Press.

Hegedüs, Zs. (in press). Burials without bodies. The symbolic burials of the Carpathian Basin and the Lower Danube region during the Late Neolithic and Copper Age. Archaeológiai Értesitö 146.

Hillebrand, J. (1927). A pusztaistvánházai rézkori temető őstörténeti jelentőségéről. Országos Magyar Régészeti Társulat Évkönyve 2, 24-40.

Hovers, E. \& Belfer-Cohen, A. (2013). Insights into early mortuary practices of Homo. In Tarlow, S. \& Nilsson Stutz, L. (eds), The Oxford Handbook of the Archaeology of Death and Burial (pp. 632-643). Oxford: Oxford University Press. https://doi.org/10.1093/oxfordhb/9780199569069.013.0035

Jones, A. (2007) Memory and Material Culture. Cambridge: Cambridge University Press. https://doi. org/10.1017/cbo9780511619229.002

Király, Á. (2016). A terminológia halálától a halál terminológiájáig. Megjegyzések a temetkezés fogalmához és a temetkezési ciklus állomásainak nevezéktanához. Tisicum. A Jász-Nagykun-Szolnok megyei Múzeumok Évkönyve 25, 297-302.

Köhler, K. (2006) A Lengyeli és a Balaton-Lasinja kultúra embertani leletei Veszprémből. A Veszprém Megyei Múzeumok Közleményei 24, 37-48.

Köhler, K. (2015). The human remains from the Boleráz burials uncovered at Pilismarót-Basaharc. In Bondár, M., T. Biró, K., Gál, E., Hamilton, D., Köhler, K. \& Torma, I., The Late Copper Age Cemetery at Pilismarót-Basaharc. István Torma's Excavations (1967, 1969-1972) (pp. 319-348). Budapest: Institute of Archaeology, Research Centre for the Humanities, Hungarian Academy of Sciences.

Koncz, I. \& Szilágyi, M. (2017). Az identitás régészetének elméleti alapjai. Archaeológiai Értesitő 142, 193-215. https://doi.org/10.1556/0208.2017.142.7

Kübler-Ross, E. \& Kessler, D. (2005). On Grief \& Grieving. Finding the Meaning of Grief Through the Five Stages of Loss. New York, London, Toronto, Sydney, New Delhi: Scribner.

Kus, S. (2013). Death and the cultural entanglements of the experienced, the learned, the expressed, the contested, and the imagined. In Tarlow, S. \& Nilsson Stutz, L. (eds), The Oxford Handbook of the Archaeology of Death and Burial (pp. 60-76). Oxford: Oxford University Press. https://doi.org/10.1093/ oxfordhb/9780199569069.013.0005

Luca, S. A. (2006). La nécropole appartenant à la culture Turdas trouvée à Orăştie-Dealul Pemilor, le lieu dit X2. Acta Terra Septemcastrensis 5 (1), 13-27. 
Hegedüs Zsuzsa • Szimbolikus temetkezések és gyász

McHugh, F. (1999). Theoretical and Quantitative Approaches to the Study of Mortuary Practice. Ann Arbor: University of Michigan Press. https://doi.org/10.30861/9781841710051

Nemejcová-Pavuková, V. (1986). Vorbericht über die Ergebnisse der systematischen Grabung in Svodín in den Jahren 1971-1983. Slovenská Archeológia 24, 133-176.

Nilssen Stutz, L. \& Tarlow, S. (2013). Beautiful things and bones of desire. In Tarlow, S. \& Nilsson Stutz, L. (eds.), The Oxford Handbook of the Archaeology of Death and Burial (pp. 1-15). Oxford: Oxford University Press. https://doi.org/10.1093/oxfordhb/9780199569069.013.0001

Novotnik, Á. (2019). Jelképes temetkezések a római császárkorban, különös tekintettel a dunai provinciákra (PhD disszertáció). Pázmány Péter Katolikus Egyetem, Bölcsészettudományi Kar, Történelemtudományi Doktori Iskola, Budapest.

Parkinson, W. A., Yerkes, R. W., Gyucha, A., Sarris, A., Morris, M., \& Salisbury, R. B. (2010). Early Copper Age settlements in the Körös region of the Great Hungarian Plain. Journal of Field Archaeology 35 (2), 164-183. https://doi.org/10.1179/009346910x12707321520675

Pérez, V.R. \& Weiss-Krejci,E. (2011). Bridging bodies. In Lillios, K.T.(ed.), Comparative Archaeologies: Prehistoric Iberia (3000-1500 BC) and the American Southwest (A.D. 900-1600) (pp. 103-120). Oxford: Oxbow Books.

Price, R. (1997). Burial practice and aspects of social structure in the Late Chalcolithic of North-East Bulgaria (PhD disszertáció). Cambridge, St. John's College, Faculty of Anthropology \& Geography, Trinity.

Rachev, R. [Рачев, P.] (2018). Simvolichnite grobove ot k'snija eneolit (po danni ot nekropolite ot teritorijata na B'lgarija) [Символичните гробове от късния енеолит (по данни от некрополите от територията на България)] (Szimbolikus sírok a késő neolitikumból (Bulgária területéről származó nekropoliszok adatai szerint)). B'lgarsko e-Spisanie za Arheologija 6, 47-57.

Raczky, P. (2009). Historical context of the Late Copper Age cemetery at Budakalász. In Bondár, M. \& Raczky, P. (eds.), The Copper Age Cemetery of Budakalász (pp. 475-484). Budapest: Pytheas Printing House.

Raczky, P. (2016). A Kárpát-medence népeinek anyagi kultúrája az újkőkor és a rézkor időszakában. In Vágó, Á. (ed.), A Kárpát-Medence ösi kincsei. A kőkortól a honfoglalásig (pp. 21-103). Budapest: Magyar Nemzeti Múzeum Kossuth Kiadó.

Raczky, P. (2019). Cross-scale settlement morphologies and social formations in the Neolithic of the Great Hungarian Plain. In Gyucha, A. (ed.), Coming Together. Comparative Approaches to Population Aggregation and Early Urbanization (pp. 259-294). New York: State University of New York Press.

Raczky, P. \& Anders, A. (2009). Tér- és időszemlélet az újkőkorban. Polgár-Csőszhalom ásatási megfigyelései. In Anders, A., Szabó, M. \& Raczky, P. (szerk.), Régészeti dimenziók. Tanulmányok az ELTE BTK Régészettudományi Intézetének tudományos mühelyéböl. A 2008. évi Magyar Tudomány Ünnepe keretében elhangzott elöadások (pp. 75-92). Budapest: Bibliotheca Archaeologica.

Raczky, P., Anders, A. \& Siklósi, Zs. (2014). Trajectories of continuity and change between the Late Neolithic and the Copper Age in Eastern Hungary. In Schier, W. \& Draşovean, F. (eds), The Neolithic and Eneolithic in Southeast Europe. New Approaches to Dating and Cultural Dynamics in the 6th to 4th Millennium BC (pp. 319-346). Rahden: Verlag Marie Leidorf GmbH. 
Hegedüs Zsuzsa $\bullet$ Szimbolikus temetkezések és gyász

Rando, T. A. (1984). Grief, Dying, and Death: Clinical Interventions for Caregivers. Champaign: Research Press.

Regenye, J. (2006). Temetkezések Veszprém, Jutasi út lelőhelyen. A Veszprém Megyei Múzeumok Közleményei 24, 7-36.

Reimers, E. (1999). Death and identity: Graves and funerals as cultural communication. Mortality 4 (2), 147-166. https://doi.org/10.1080/713685976

Siklósi, Zs. (2013). Traces of Social Inequality during the Late Neolithic in the Eastern Carpathian Basin. Budapest: Eötvös Loránd University, Institute of Archaeological Sciences.

Sofaer-Derevenski, J. (1997). Engendering children, engendering archaeology. In Moore, J. \& Scott, E. (eds), Invisible People and Processes: Writing Gender and Childhood into European Archaeology (pp. 192-202). London: Leicester University Press.

Stratton, S. (2016). Burial and Identity in the Late Neolithic and Copper Age of South-East Europe (PhD disszertáció). Cardiff University, School of History, Archaeology and Religion, Cardiff.

Stratton, S. \& Borič, D. (2012). Gendered bodies and objects in a mortuary domain: Comparative analysis of Durankulak cemetery. In Kogălniceanu, R., Curcă, R-G., Gligor, M. \& Stratton, S. (eds), Homines, Funera, Astra. Proceedings of the International Symposium on Funerary Anthropology. 5-8 June 2011 ' 1 Decembrie 1918' University (Alba Iulia, Romania) (pp. 71-79). Oxford: Archaeopress.

Stroebe, M. \& Schut, M. (1999). The dual process model of coping with bereavement: Rationale and description. Death Studies 23, 197-224. https://doi.org/10.1080/074811899201046

Thomas, K. J. A. (2020). Child deaths in the past, their consequences in the present, and mortality conditions in sub-Saharan Africa. Proceedings of the National Academy of Sciences of the United States of America 117 (9), 4453-4455. https://doi.org/10.1073/pnas.2000435117

Weiss-Krejci, E. (2011). The formation of mortuary deposits: Implications for understanding mortuary behavior of past populations. In Agarwal, S. C. \& Glencross, B. A. (eds), Social Bioarchaeology (pp. 68-106). Chichester: Wiley-Blackwell. https://doi.org/10.1002/9781444390537.ch4

Weiss-Krejci, E. (2013). The unburied dead. In Tarlow, S. \& Nilsson Stutz, L. (eds), The Oxford Handbook of the Archaeology of Death and Burial (pp. 281-302). Oxford: Oxford University Press. https://doi. org/10.1093/oxfordhb/9780199569069.013.0016

Worden, J. W. (2009). Grief Counselling and Grief Therapy. A Handbook for the Mental Health Practitioner. New York: Springer. https://doi.org/10.1891/9780826101211

Zalai-Gaál, I. (1988). Közép-európai neolitikus temetők szociálarchaeológiai elemzése. A Szekszárdi Béri Balogh Ádám Múzeum Évkönyve 14, 3-178.

Zur, J. N. (1998). Violent Memories. Mayan War Widows in Guatemala. Boulder: Westview Press. https:// doi.org/10.4324/9780429503245 